\section{UDC 351.83}

\section{Diegtiar Andrii Olegovich,}

Doctor of Public Administration, Professor, Honored Science and Technology Worker of Ukraine Head of Department of management and administration of Kharkiv state academy of culture, 61057, Kharkiv, Bursaczky'j spusk, 4, tel.: +38 (095) 57220 91, E-mail: ADegtyar@3g.ua

$$
\text { ORCID: 0000-0003-3258-447X }
$$

\section{Дегтяр Андрій Олегович,}

доктор наук з державного управління, професор, Заслужений діяч науки і техніки України, Завідувач кафедри менеджменту і адміністрування Харківської державної академії культури, 61057, Харків, Бурсащький узвіз, 4, тел.: +38 (095) 57220 91,E-mail:ADegtyar@3g.ua

ORCID: 0000-0003-3258-447X

\section{Дегтярь Андрей Олегович,}

доктор наук по государственному управлению, профессор, Заслуженный деятель науки и техники Украины, Заведующий кафедры менеджмента и администрирования Харьковской государственной академии культуры, 61057, Харьков, Бурсаикий спуск, 4, тел.: +38 (095) 57220 91, E-mail: ADegtyar@3g:ua

$$
\text { ORCID: 0000-0003-3258-447X }
$$

Serohina-Berestovska Oksana Victorivna, Applicant for a degree of Department of Political Science and Philosophy of Kharkiv regional institute of Public Administration of National academy for Public administration under the President of Ukraine, 61057, Kharkiv, Bursaczky'j spusk, 4, tel.: +38 (095) 572 20 91,e-mail:ADegtyar@3g.ua ORCID: 0000-0002-1150-8921

\section{Серьогіна-Берестовська Оксана Вікторівна,} здобувач кафедри політології та філософіі Харківського регіонального інституту державного управління Наиіональної академії державного управління при Президентові України, 61057, Харків, Бурсащький узвіз, 4, тел.: +38 (095) 57220 91, е-таіl: ADegtyar@3g.ua

ORCID: 0000-0002-1150-8921
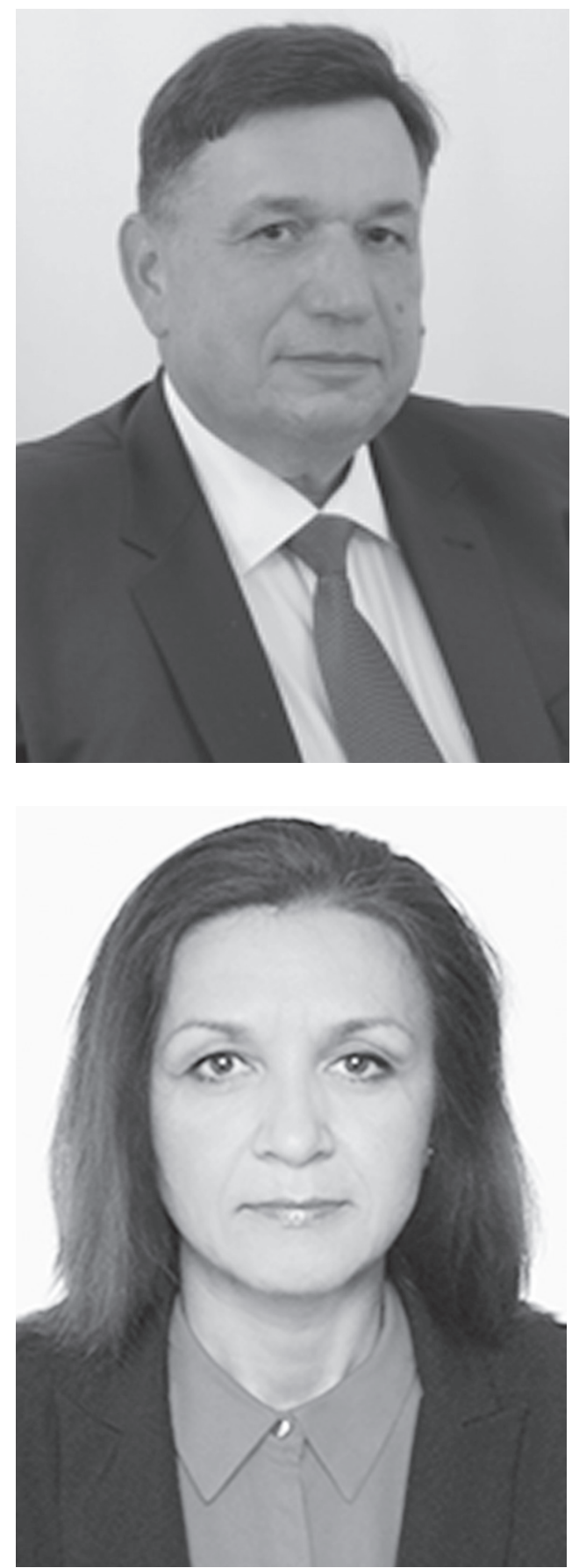
Серегина-Берестовская Оксана Викторовна, соискатель кафедры политологии и философии Харьковского регионального института государственного управления Национальной академии государственного управления при Президенте Украины, 61057, Харьков, Бурсаикий спуск, 4, тел.: +38 (095) 572 20 91, e-mail:ADegtyar@3g.ua

\title{
THEORETICAL ASPECTS OF MANAGEMENT OF DEVELOPMENT OF SOCIAL INFRASTRUCTURE IN THE REGION
}

\begin{abstract}
The article summarizes the theoretical and methodological aspects of the development of social infrastructure in the region, identifies the main stages of its development, types and characteristics of the system, which together form the basis for further methodological research and determine the importance of social infrastructure for the socio-economic development of the regions of Ukraine.

Trends in the development of social infrastructure intensified until the middle of the XX century, as a consequence of the formation of a market economy. Within the framework of the scientific and technical revolution, there was a need, firstly, to increase the quality parameters of the personnel at the expense of intelligence, promotion of healthy lifestyles, deformation of the motives of work, which involved the formation of various sectors of social infrastructure; secondly, in the areas of social infrastructure, a new material and technical base was created, which provided high efficiency of its functioning; third, the development of material production sectors was accompanied by a significant reduction in social disparities.

Creation, development and support of infrastructure, including social, in Ukraine, as well as in the world - the task of the state. Effective functioning and development of the social infrastructure of the regions is possible only with comprehensive and integrated state support. In the article it is found out that the main tasks of management of processes of creation of social infrastructure in Ukraine in modern conditions are: to correspond to dynamics of changes in economic system and in due time to react to new factors of influence; to carry out the analysis of theoretical laws of formation of social infrastructure; to assess the state of national infrastructure in General and social infrastructure in particular and what has happened in Ukraine in recent years, reducing the factors of infrastructure growth; to show the role of social infrastructure as a fundamental basis in the construction of a modern city; to find ways to create a social infrastructure adequate to the transformations that occur within the country; to identify patterns that affect the change of existing standards of formation and modernization of social infrastructure.
\end{abstract}


Keywords: state, management, infrastructure, social infrastructure, management of social infrastructure, objects of social infrastructure, tasks of management of processes of creation of social infrastructure.

\section{ТЕОРЕТИЧНІ АСПЕКТИ УПРАВЛІННЯ РОЗВИТКОМ СОЦІАЛЬНОЇ ІНФРАСТРУКТУРИ РЕГІОНУ}

Анотація. Узагальнено теоретичні та методологічні аспекти розвитку соціальної інфраструктури регіону, виявлені основні етапи їі розвитку, типи і характеристики системи, які разом утворюють основу для подальших методологічних досліджень і визначають значущість соціальної інфраструктури для соціально-економічного розвитку регіонів України.

Тенденції розвитку соціальної інфраструктури активізувалися до середини XX ст., як наслідок формування ринкової економіки. У рамках науково-технічної революції виникла потреба, по-перше, збільшення якісних параметрів кадрового складу за рахунок інтелекту, пропаганди здорового способу життя, деформації мотивів праці, що передбачало формування різних галузей соціальної інфраструктури; по-друге, у сферах соціальної інфраструктури була створена нова матеріально-технічна база, яка забезпечувала високу ефективність іiї функціонування; по-третє, розвиток галузей матеріального виробництва супроводжувався значним скороченням соціальних диспропорцій.

Створення, розвиток і підтримка інфраструктури, у тому числі і соціальної, в Україні, як і в усьому світі - завдання держави. Ефективне функціонування і розвиток соціальної інфраструктури регіонів можливий тільки за умови всебічної та комплексної державної підтримки. Обгрунтовано, що головними завданнями управління процесами створення соціальної інфраструктури в Україні в сучасних умовах є такі: відповідати динаміці змін у господарській системі і своєчасно реагувати на нові фактори впливу; здійснювати аналіз теоретичних закономірностей формування соціальної інфраструктури; оцінювати стан національної інфраструктури в цілому та соціальної інфраструктури, зокрема і те, що сталося в Україні за останній період зниження факторів зростання інфраструктури; показати роль соціальної інфраструктури як фундаментальної основи в конструюванні сучасного міста; знайти шляхи створення соціальної інфраструктури, адекватної перетворенням, що відбуваються всередині країни; виявити закономірності, які впливають на зміну існуючих стандартів формування та модернізації соціальної інфраструктури.

Ключові слова: держава, управління, інфраструктура, соціальна інфраструктура, управління створенням соціальної інфраструктури, об'єкти соціальної інфраструктури, задачі управління процесами створення соціальної інфраструктури.

\section{ТЕОРЕТИЧЕСКИЕ АСПЕКТЫ УПРАВЛЕНИЯ РАЗВИТИЕМ СОЦИАЛЬНОЙ ИНФРАСТРУКТУРЫ РЕГИОНА}

Аннотация. Обобщены теоретические и методологические аспекты развития социальной инфраструктуры региона, выявлены основные этапы ее 
развития, типы и характеристики системы, которые вместе образуют основу для дальнейших методологических исследований и определяют значимость социальной инфраструктуры для социально-экономического развития регионов Украины.

Тенденции развития социальной инфраструктуры активизировались до середины XX в., как следствие формирования рыночной экономики. В рамках научно-технической революции возникла потребность, во-первых, увеличение качественных параметров кадрового состава за счет интеллекта, пропаганды здорового образа жизни, деформации мотивов труда, что предполагало формирование различных отраслей социальной инфраструктуры; во-вторых, в сферах социальной инфраструктуры была создана новая материально-техническая база, которая обеспечивала высокую эффективность ее функционирования; в-третьих, развитие отраслей материального производства сопровождалось значительным сокращением социальных диспропорций.

Создание, развитие и поддержка инфраструктуры, в том числе и социальной, в Украине, как и во всем мире - задача государства. Эффективное функционирование и развитие социальной инфраструктуры регионов возможен только при условии всесторонней и комплексной государственной поддержки. Обосновано, что главными задачами управления процессами создания социальной инфраструктуры в Украине в современных условиях являются такие: соответствовать динамике изменений в хозяйственной системе и своевременно реагировать на новые факторы влияния; проводить анализ теоретических закономерностей формирования социальной инфраструктуры; оценивать состояние национальной инфраструктуры в целом и социальной инфраструктуры в частности и то, что произошло в Украине за последнее время снижение факторов роста инфраструктуры; показать роль социальной инфраструктуры как фундаментальной основы в конструировании современного города; найти пути создания социальной инфраструктуры, адекватной преобразованиям, что происходят внутри страны; выявить закономерности, которые влияют на изменение существующих стандартов формирования и модернизации социальной инфраструктуры.

Ключевые слова: государство, управление, инфраструктура, социальная инфраструктура, управление созданием социальной инфраструктуры, объекты социальной инфраструктуры, задачи управления процессами создания социальной инфраструктуры.

Problem statement. The processes of globalization, characterized by the transformation of the global economic trends of a socially oriented market economy, which requires in-depth study of the objective laws of social development to create new mechanisms to increase the quality of life of the population. Social infrastructure occupies one of the most important places 
in the economy of any state, as well as in the economies of individual regions. Currently, sociologists, economists, political scientists around the world agree that the health of the population, its level of education and skills are among the leading factors of economic growth. Investing today in the development of social infrastructure, through which the population receives the necessary material and social benefits, a set of social rights and guarantees, the state is preparing the foundation for its socioeconomic well-being in the future.

Analysis of recent research and publications. Problems of management of development of social infrastructure of the region are covered in the works of both foreign and domestic scientists. A significant contribution to the study of the influence of the state on the social and economic relations was made by such scientists P. Bielienkyi [6], M. Butko [2], A. Vsyliev [3], B. Danylyshyn [4], N. Ivanova [2], S. Kyrychenko [11], L. Kovalska [9], M. Komarov [10], V. Krasovskyi [8], S. Ishchuk [7], T. Kulinich [7], V. Krupin [7], [9], S. Tkach [7], A. Tkach [12], etc. The ideas and provisions set out in the works of these authors served as the basis for the further development of social infrastructure. However, despite numerous studies, they have a general scientific meaning and are characterized by a more descriptive nature.

Formulation of the aims of the article. The purpose of this article is to study the main theoretical aspects of management of social infrastructure development in the region in Ukraine.

Presentation of the main material of the study. Trends in the development of social infrastructure intensified until the middle of the XX century, as a consequence of the formation of a market economy. Within the framework of the scientific and technical revolution, there was a need, firstly, to increase the quality parameters of the personnel at the expense of intelligence, promotion of healthy lifestyles, deformation of the motives of work, which involved the formation of various sectors of social infrastructure; secondly, in the areas of social infrastructure, a new material and technical base was created, which provided high efficiency of its functioning; third, the development of material production sectors was accompanied by a significant reduction in social disparities.

Scientific approaches to the definition of problems of life as a society as a whole, and a single individual were determined before this phenomenon was framed in a separate category of concepts.

The term "infrastructure" appeared in science in the 40-ies of XX century, and in 50-ies of the twentieth century when scientists began using it to explain economic processes. The concept of "infrastructure" in the general context provides for sectoral management, serving industrial and agricultural production [3, p. 64].

As a result, the spread of this term occurred both in the framework of economic teachings, and later in the framework of the teachings of society. A specific characteristic in the definition of approaches to the interpretation of this concept was not only the material and technical support, but also the assessment of quality parameters of life of the population in terms of meeting their needs. Thus, P. Rosenstein-Rodan con- 
siders infrastructure as a systematized environment conducive to the favorable development of the private sector in the sectoral structure of the economy, the main purpose of which is to meet the needs of the population [12, p. 62].

D. Galbraith put forward the view that the development of economic imbalance is in direct dependence on public consumption, as the entire resource base is fully consumed in the production of consumer goods, and not leave enough resources to meet public needs and infrastructure [2, p. 91].

The interdependence of economic interests and objective laws in the structuring of infrastructure elements, primarily provide for the activities of human labor. Further, the formation of infrastructure echoed with the increase in the level of availability of consumer conditions as a single individual (employee) and his family.

In Russian economic science at the turn of 60-70-years of XX century, the problems, including the formation of environmental, industrial and social infrastructure have intensified, since at the beginning of the 80 -ies of the twentieth century the term "market infrastructure" comes in the practice that defines the subsystem of the sphere of circulation [7, p. 57]. The specific variability of infrastructure leads to the conclusion that within the framework of modernization there are new forms of structures that subsequently form new types of relevant infrastructure.

Separating infrastructure subsystems by the scale of formation, it should be noted that economic structures are the constituent elements of each system and act as systems themselves, as they have the appropriate infrastructure.
Let us dwell on the regional infrastructure, which is associated with all kinds of social reproduction. In the structure of this complex the processes associated with material production, and the diversity of spheres of human activity, including the social sphere are concentrated. Negative factors hindering the formation and development of regional infrastructure have a negative impact on the dynamics of the economy of the region as a whole.

Over time, the opinion on the elements of the regional infrastructure evolved from a complex of military structures to the underlying national economy - public subsidiary of capital, which is conducive to sustainable industrial and socio-economic development of the territories [4, p. 75].

By form of ownership infrastructure is divided into: state, municipal, private and mixed. As a subject of public infrastructure the authorities and organizations of the state and regional level act, the property of individuals and legal entities is a private infrastructure, a mixed one provides for public-private partnership.

Regional infrastructure in modern reality is represented by a multi-level organizational and economic system, including: production, social, network, institutional and life support infrastructure.

L. Kovalska gives the following definition of social infrastructure as such, which is a subsystem of the economy, which creates and implements social infrastructure benefits - general conditions of operation of the society as a subject of economic decision-making throughout the economy and the object of formation of the endogenous 
rules of decision-making (institutions), that is represented by a set of organizations and facilities of housing, culturalhousehold, commercial and medical purposes [6, p. 68].

Creation, development and support of infrastructure, including social, in Ukraine, as well as in the world is the task of the state. Effective functioning and development of the social infrastructure of the regions is possible only with comprehensive and integrated state support. Program-target planning is such a tool of state support.

Another mechanism of support and development of social infrastructure in the regions is the mechanism of publicprivate partnership (PPP). The experience of Western countries with developed economies shows that the state cannot solve large projects on its own without outside investment and business support.

Regions have great prospects for the development of PPP, if the state provides guarantees for a minimum profit from the project, and banking institutions and insurance companies reduce investment risks. This will attract not only large but also small firms. For example, business begins to actively develop in the fields of infrastructure construction, education and health, but with sufficient participation of the state or in the form of budget resources or preferential terms for investments [1, p. 82].

The main tasks of management of processes of creation of social infrastructure in Ukraine in modern conditions are as follows:

1. To correspond to the dynamics of changes in the economic system and respond to new factors of influence.
2. To conduct the analysis of theoretical regularities of formation of social infrastructure.

3 . To assess the state of national infrastructure in general and social infrastructure in particular and what has happened in Ukraine in recent years, the reduction of factors of infrastructure growth.

4. To show the role of social infrastructure as a fundamental basis in the construction of a modern city.

5 . To find ways to create a social infrastructure adequate to the changes that are taking place within the country.

6. To identify patterns that affect the change in existing standards of formation and modernization of social infrastructure.

7. To adapt new standards in the Ukrainian climatic, geographic, and economic features.

The result of solving the above tasks should be: evaluation, standards, evidence-based programs, model of social infrastructure and scientific and conceptual conclusions and recommendations.

A special place in the management system is played by the analysis. Economic analysis is a general methodology, a way of solving problems as a management function involves the assessment of internal and external factors of the situation, trends of development of production processes, the possible reserves of increasing the effectiveness of social infrastructure [10, p. 56].

Thus, we can conclude that for the harmonious development of the social infrastructure it is reasonably necessary to have increase of capacity (introduction of new places in kindergartens, 
schools, increase the number of beds and the like) [5, p. 43].

The main role in the system of regional infrastructure is given to social infrastructure, which, based on its specific structure, which includes a set of quantitative and qualitative parameters of social well-being, determines the regional social structure.

The analysis of social infrastructure is based on the following set of methods:

1. System; this method considers the object as a system with all its components - subsystems, reveals the relationship between them, and determines the degree of influence of the environment on the object;

2. Situational; this method involves the analysis of any situation, using typical research processes;

3. Dialectical; it represents the base of special research methods: necessary and random, abstract and concrete, crushing and combining General and particular, main and concrete, statics and dynamics

4. Reflexive; this method as a home base involves the analysis of systematized and available information about internal and external environment of the object [10, p. 251].

As the social infrastructure of the region one should consider an industry complex (education, culture and art, health, physical education and sports), whose function is to ensure sustainable regional socio-economic development, improve the quality of life of the population and contribute to the rational organization of activities.

The main elements of the regional social infrastructure include the following types of resources:
- capital structures, buildings, equipment, etc.);

- non-financial (information support, personnel services, etc);

- organizational and managerial (planning, organization, control, functioning, etc.) [11, p. 52].

It should be noted that organizational and managerial resources act as a link between capital and non-financial elements of social infrastructure.

The social infrastructure of the region is separated by the main system characteristics: consistency; functionality, dynamism.

The main function of the social infrastructure is the provision of various non-productive services that meet the vital needs of the population, which are:

- protection and improvement of public health;

- satisfaction of the conditions for the reproduction of a population of power;

- formation of conditions for progressive dynamics of demographic processes;

- implementation of the principle of accessibility of social infrastructure services throughout the region, means of smoothing territorial imbalances in the socio-economic development of the region;

- development of the basic conditions for the full realization of the abilities of each individual by means of the structuring of consumer values [9, p. 37].

Elements of social infrastructure should be structured on the basis of the following criteria: industry structure, composition, nature of objects, level of development of consumer value. 
According to the sectoral structure the social infrastructure is determined by the branches of education, culture and sports, health, physical education and sports.

The corporate level of social infrastructure is aimed at the employees of the companies, and the territorial level is focused on the properties of life of the population of the region as a whole.

The social infrastructure is divided into "hard" and "soft". A "hard" one includes structures, buildings, that is, all that is the material basis for the implementation of socio-economic activities. "Soft" one includes non-financial and organizational management resources that are associated with the provision of services and in most cases difficult to define and measurable, often described by subjective characteristics.

From the point of view of providing services to the consumer, the social infrastructure includes the following elements:

1. Universal services (medical services, educational services, sports, leisure activities);

2. Objects that are designed to provide services throughout the life cycle from birth to the end of life act as targeted services (kindergartens, educational institutions, pension funds);

3. Services for people with special needs and disabilities. In this context, dynamism is defined by processes such as modernization and transformation. Modernization processes, as a result of which there is an accumulation of quantitative transformations of elements and relationships between them, then flow into the transformation processes.

According to the cycle of functioning, social infrastructures are divided by maturity into: developing countries, developed countries and "output" elements. At each stage of the cycle there may be different states, which are characterized by a certain set of parameters, the functioning of which depends on the dynamics of the phenomenon. As a result, this fact allows to split subclasses: dominant, stagnant, crisis, depressive and such that social infrastructure is being transformed.

The level of development distinguishes the infrastructure that is behind the previous system and the new one that is being formed. In the development of infrastructure there are slow and consistent changes, adaptation, but there can be a sharp change of "gradual breaks", which are the result of socio-economic crises of the economic system.

Conclusions from this study and prospects for further exploration. Analysis of the system characteristics of the social infrastructure of the region allows to determine its features:

1. Social infrastructure sectors complement each other, some infrastructure cannot be replaced by others, they coexist only in a complex, interactive environment.

2. As a product of social infrastructure a service that does not create a new product, and are the result of work, which adds new value to the value of the already created product should be considered.

3. Social infrastructure services are not transferred, they are provided only to the population of the region, they can not be imported, they are not subject to storage, accumulation or reservation.

4. The demand for social infrastructure services is individual. In some 
periods of life, a person needs services for the upbringing of children, after that - the need for higher professional education, for some - the need for sports, for others - the need for culture. At the same time, there are people with disabilities, as well as special needs related to traditions and ethnic relations. Consequently, social infrastructure cannot be viewed in isolation from the values and orientations of individuals, groups and associations.

\section{REFERENCES}

1. Vasy'l'yev O. V. (2007), Metodologiya i prakty'ka infrastrukturnogo zabezpechennya funkcionuvannya i rozvy'tku regioniv Ukrayiny' [Methodology and practice of infrastructure of functioning and development of regions of Ukraine], XNAMG publ., Kharkiv, Ukraine.

2. Gelbreyt J. K. (2008), Novoe industrialnoe obschestvo [New industrial society], Eksmo publ., Moscow, Russia.

3. Encyklopediya biznesmena, ekonomista, menedzhera (2002), [Encyclopedia of businessman, economist, manager], Mizhnarodna ekonomichna fundaciya publ. Kyiv, Ukraine.

4. Byelyen'kogo P. Yu. (2002), Infrastrukturne zabezpechennya konkurentnoyi ekonomiky' regioniv (metodologiya i mexanizmy') [Infrastructure support of competitive economy of regions (methodology and mechanisms)], NANU In-t reg. doslidzh. Publ. L'viv, Ukraine.

5. IshhukS.O., Kulinich T.V., Krupin V. Ye., Tkach S. M. (2010), Infrastrukturny'j kompleks Zaxidnogo regionu Ukrayiny': ocinka stanu i napryamy' rozvy'tku [Infrastructure complex of the Western region of Ukraine: as- sessment of the state and direction of development], NAN Ukrayiny'. In-t regional'ny'x doslidzhen' publ., L'viv, Ukraine.

6. Koval's'ka L. L. (2012), Social'na infrastruktura regionu: mexanizmy' formuvannya ta rozvy'tku [Social infrastructure of the region: mechanisms of formation and development], Zh. V. Gadyak publ., Lucz'k, Ukraine.

7. Ky'ry'chenko C. O. (2016), "Approaches to definition of essence of concept "social infrastructure" and its functionality", Problemy' sy'stemnogo pidxodu v ekonomici, vol. 1 (55), p. 56-60.

8. Tkach A.A. (2005), Instytucional'ni osnovy' ry'nkovoyi infrastruktury' [The Institutional framework of the market infrastructure], NANU Ob'yednany'j in.-t ekonomiky' publ., Kyiv, Ukraine.

9. Novikov B. M., Dyeyeva N. M., Kalenyuk I. S. (2015), Transformaciya social'noyi infrastruktury' $\mathrm{v}$ konteksti zabezpechennya gumanitarnogo rozvy'tk [Transformation of social infrastructure in the context of humanitarian development], PP Balyuk I. B. publ., Vinny'cya, Ukraine.

10. Tretyak V. P. (2014), Upravlinnya rozvy'tkom social'noyi infrastruktury' Ukrayiny' v umovax globalizaciyi [Management of social infrastructure development in the context of globalization], XNU imeni V. N. Karazina publ., Kharkiv, Ukraine.

11. Chernyuk L. G. (2012), "Social infrastructure and its priority in the system of social development (methodological and organizational aspects)", Visny'k Chernigivs'kogo derzh. un-tu., vol. 1 (56), p. 10-20.

12. Rosenstein-Rodan. P. (1961), "Notes on the Theory of the "Big Push", Economic Development for Latin America, vol. 1, p. 60-69. 


\section{СПИСОК ВИКОРИСТАНИХ ДЖЕРЕЛ}

1. Васильєв О. В. Методологія і практика інфраструктурного забезпечення функціонування і розвитку регіонів України: монографія / О. В. Васильєв. - Х. : ХНАМГ, 2007. - 341 с.

2. Гэлбрейт Дж. К. Новое индустриальное общество. Избранное / Дж. К. Гэлбрейт. - М. : Эксмо, 2008.$1200 \mathrm{c}$.

3. Енииклопедія бізнесмена, економіста, менеджера / за ред. Р. Дяківа. К. : Міжнар. економічна фундація, 2002. - $704 \mathrm{c}$.

4. Інфраструктурне забезпечення конкурентної економіки регіонів (методологія і механізми) / за ред. П. Ю. Бєлєнького. - Львів: НАНУ Ін-т регіон. досліджень, 2002. - 308 с.

5. Інфраструктурний комплекс Західного регіону України: оцінка стану і напрями розвитку : монографія / [С. О. Іщук, Т. В. Кулініч, В. С. Крупін, С. М. Ткач]; НАН України. Ін-т регіональних досліджень; [наук. ред. С. О. Іщук]. - Львів :[б. в.], 2010. $242 \mathrm{c}$.

6. Ковальська Л. Л. Соціальна інфраструктура регіону: механізми формування та розвитку : монографія / Л. Л. Ковальська, О. М. Салівончик; М-во освіти і науки, молоді та спорту України, Луцький нац. техн. ун-т. Луцьк : Ж. В. Гадяк, 2012. -226 с.
7. Кириченко С. О. Підходи до визначення сутності поняття “соціальна інфраструктура” та її функціональне призначення / С. О. Кириченко // Проблеми системного підходу в економіці. - № 1 (55). - 2016. C. 56-60.

8. ткач A. А. Інституціональні основи ринкової інфраструктури: монографія / А. А. Ткач. - К. : НАНУ Об'єднаний ін.-т економіки, 2005. - 295 с.

9. Трансформація соціальної інфраструктури в контексті забезпечення гуманітарного розвитку : кол. монографія / В. М. Новіков, Н. М. Дєєва, I. C. Каленюк та ін. ; за наук. ред. В. М. Новікова, 3. С. Сіройча. - Вінниця : ПП Балюк І. Б., 2015. - 384 с.

10. Третяк В. П. Управління розвитком соціальної інфраструктури України в умовах глобалізації : монографія / В. П. Третяк. - Х. : ХНУ ім. В. Н. Каразіна 2014. - $317 \mathrm{c}$.

11. Чернюк Л. Г. Соціальна інфраструктура та їі пріоритетність в системі суспільного розвитку (методологоорганізаційні аспекти) / Л. Г. Чернюк, П. В. Пепа // Вісн. Чернігів. держ. ун-ту. - Вип. 1 (56). - 2012. C. 10-20.- (Серія: економічні науки).

12. Rosenstein-Rodan P. Notes on the Theory of the "Big Push" // Economic Development for Latin America. № 1. - 1961. - P. 60-69. 